\title{
Gas vesicle collapse by turgor pressure and its role in buoyancy regulation by Anabaena flos-aquae
}

\author{
R. Kinsman, ${ }^{1}$ B. W. Ibelings ${ }^{2}$ and A. E. Walsby ${ }^{1 *}$ \\ ${ }^{1}$ Department of Botany, University of Bristol, Bristol BS8 IUG, UK \\ ${ }^{2}$ Laboratory of Microbiology, University of Amsterdam, Niewe Achtergracht 127, 1018 WS Amsterdam, \\ The Netherlands
}

(Received 5 October 1990; revised 10 December 1990; accepted 9 January 1991)

\begin{abstract}
Filaments of Anabaena flos-aquae lost over half of their gas vesicles when exposed to light of high irradiance ( $>115 \mu \mathrm{mol} \mathrm{m} \mathrm{m}^{-2} \mathrm{~s}^{-1}$ ) for long periods (up to $23 \mathrm{~h}$ ). An investigation using different irradiances showed that the major loss of gas vesicles occurred after prolonged exposure to irradiances exceeding $80 \mu \mathrm{mol} \mathrm{m}^{-2} \mathrm{~s}^{-1}$. In a timecourse experiment it was found that $56 \%$ of the gas vesicles were lost after $16 \mathrm{~h}$ exposure to an irradiance of $135 \mu \mathrm{mol} \mathrm{m} \mathrm{m}^{-2} \mathrm{~s}^{-1}$. Most of this loss could be accounted for by collapse under turgor pressure, which rose by $0 \cdot 24$ MPa to 0.54 MPa after $16 \mathrm{~h}$. A further unexplained loss of $15 \%$ after $23 \mathrm{~h}$ exposure may indicate that prolonged high irradiance can cause weakening of gas vesicles in the cells. In this time-course experiment $98 \%$ of the filaments lost their buoyancy after $6 \mathrm{~h}$ exposure, before any gas vesicles were lost; this buoyancy change was quantitatively accounted for by the rise in cell carbohydrate. The relative importance of gas vesicle collapse and carbohydrate accumulation as mechanisms of buoyancy loss is discussed in relation to vertical movements of planktonic cyanobacteria in lakes.
\end{abstract}

\section{Introduction}

Planktonic cyanobacteria derive their buoyancy from gas vesicles. It was shown in Anabaena flos-aquae that the gas vesicle content was highest in cells cultured at low irradiance and that transfer to high irradiances could cause a rapid loss of buoyancy (Walsby, 1971). It was speculated that the buoyancy loss occurred either as a consequence of gas vesicle production not keeping pace with the accumulation of new cell material or through the collapse of gas vesicles under increasing cell turgor pressure (Walsby, 1970). Cells grown at high irradiances were shown to produce higher turgor pressures that would have caused some of the weaker gas vesicles to collapse (Walsby, 1971). Dinsdale \& Walsby (1972) showed that an increase in irradiance caused a turgor rise of over $0.1 \mathrm{MPa}$ in only $4 \mathrm{~h}$ and that this accounted for the collapse of the weaker gas vesicles and the loss of buoyancy by the filaments. The turgor rise was dependent on photosynthesis : about half the rise was generated by photosynthetic products (Grant \& Walsby, 1977) and half by the light-stimulated uptake of potassium ions (Allison \& Walsby, 1981).

The development of methods for measuring the buoyant density of cells (Oliver et al., 1981), gas vesicle volume (Walsby, 1982) and the ballast mass of the other principal cell components (i.e. their mass minus the mass of water they displaced) made it possible to determine the causes of buoyancy loss in different cyanobacteria (Oliver et al., 1982; Oliver \& Walsby 1984). The major cause of density increase in filaments of Anabaena flosaquae, after a day's exposure to high irradiance (120$\left.150 \mu \mathrm{mol} \mathrm{m} \mathrm{m}^{-2} \mathrm{~s}^{-1}\right)$, was the decrease in gas vesicle content, to half of the original value: increases in ballast contributed by protein and carbohydrate would not have been large enough by themselves to have counteracted the initial state of buoyancy (Oliver \& Walsby, 1984).

The cause of buoyancy loss was different, however, in other cyanobacteria that possessed gas vesicles too strong to be collapsed by turgor pressure. In Oscillatoria agardhii gas vesicle production ceased on transfer to high irradiance; buoyancy was lost due to the accumulation of carbohydrate and, to a lesser extent, protein (Oliver et al., 1982; Utkilen et al., 1985). In Microcystis sp. buoyancy loss could be accounted for entirely by the increase in carbohydrate (Thomas \& Walsby, 1985). Diel changes in carbohydrate content, which increased during the day and decreased at night, were found to be 
positively correlated with changes in cell density and inversely correlated with the buoyancy state (Kromkamp \& Mur, 1984; Thomas \& Walsby, 1986; Konopka et al., $1987 a$; Kromkamp et al., 1988). These quantitative studies have shown that there are at least three physiological mechanisms - gas vesicle collapse, cessation of gas vesicle synthesis, and carbohydrate accumulation - which may contribute to the loss of buoyancy by cyanobacteria at high irradiance.

Studies on planktonic cyanobacteria in lakes have shown that buoyancy regulation in response to light explains how these organisms perform controlled vertical migrations (Walsby \& Klemer, 1974; Konopka et al., 1978; Walsby et al., 1983). In some cases buoyancy loss at high irradiances near the water surface has been correlated with rise in turgor pressure (Walsby \& Klemer, 1974; Reynolds, 1973, 1975; Konopka et al., 1978; Konopka, 1982) though it was not shown that turgor rise was the cause of the buoyancy loss. In other instances buoyancy loss has been correlated with carbohydrate rise (e.g. van Rijn \& Shilo, 1985) or shown to be caused by carbohydrate accumulation (Walsby et al., 1989; B. W. Ibelings and others, unpublished). Detailed studies by Kromkamp et al. (1986) and Konopka et al. (1987b) on Aphanizomenon flos-aquae have also called into question the importance in buoyancy regulation of gas vesicle collapse by turgor pressure. They found that carbohydrate accumulation caused buoyancy loss after only $2 \mathrm{~h}$ at high irradiance whereas gas vesicle loss occurred only after $5 \mathrm{~h}$.

These findings have prompted our reinvestigation of the mechanism of buoyancy loss by Anabaena flos-aquae, in which a number of uncertainties remained. First, the experiments of Oliver \& Walsby (1984) showed a large loss of gas vesicles (up to $50 \%$ ) after $24 \mathrm{~h}$ but no information was obtained on changes over shorter periods. Secondly, although substantial short-term turgor pressure rises had been demonstrated in this organism (Grant \& Walsby, 1977; Allison \& Walsby, 1981) they would not have caused as much as $50 \%$ of the gas vesicles to collapse. The largest turgor rise, observed by Dinsdale $\&$ Walsby (1971), was $0.17 \mathrm{MPa}$ over $4 \mathrm{~h}$ at $10 \mathrm{klx}$ (about $200 \mu \mathrm{mol} \mathrm{m} \mathrm{m}^{-2} \mathrm{~s}^{-1}$, which caused collapse of only $15 \%$ of the gas vesicles. Thirdly, no information was available on the short-term changes in carbohydrate.

To resolve these uncertainties we have performed detailed quantitative analyses of the major factors that affect buoyancy during the exposure of Anabaena flosaquae to light of high irradiance. The study was facilitated by the development of a capillary compression tube in which replicate measurements of gas vesicle volume could be made at frequent intervals. The investigation has demonstrated the rapid accumulation of carbohydrate, which can cause buoyancy loss before there is significant destruction of gas vesicles. It has also demonstrated turgor rises that were higher than previously recorded and do cause collapse of half the gas vesicles within a $16 \mathrm{~h}$ light period. These findings are discussed in relation to buoyancy regulation by waterbloom-forming cyanobacteria.

\section{Methods}

Cultures. Anabaena flos-aquae CCAP 1403/13F (Booker \& Walsby, 1979), the same strain as used by Oliver $\&$ Walsby (1984) and in other investigations referred to above, was cultured in the medium described by Walsby \& Booker (1980). Cultures were grown with aeration at $20^{\circ} \mathrm{C}$ at a photosynthetically active photon irradiance (PAR) of $20 \mu \mathrm{mol} \mathrm{m} \mathrm{m}^{-2} \mathrm{~s}^{-1}$, Buoyant filaments that had floated were harvested from the surfaces of cultures left standing at $5 \mu \mathrm{mol} \mathrm{m}^{-2} \mathrm{~s}^{-1}$ overnight.

Exposure to light. Shallow layers $(<5 \mathrm{~mm})$ of cultures in 2-litre capacity Erlenmeyer flasks were bubbled with moist air at 0.8 litres $\mathrm{min}^{-1}$ and illuminated from below with five fluorescent lamps (Thorn $30 \mathrm{~W}$ warm white). The PAR was determined by measurements with a Macam quantum sensor held at the illuminated bottom surface $\left(I_{0}\right)$ and just above the culture $\left(I_{b}\right)$ and the mean irradiance in the culture was calculated by integration, with the equation of van Liere \& Walsby (1982).

Buoyancy state. Samples of the suspension were left in a haemocytometer chamber (depth $0.4 \mathrm{~mm}$ ) for $15 \mathrm{~min}$ to allow the separation of floating filaments, under the coverslip, and sinking filaments, on the platform. Counts of the two classes were made by microscopy (Walsby \& Booker, 1980).

Turgor pressure. Measurements were made by pressure nephelometer of the critical pressure distribution of gas vesicles in cells suspended in culture medium and in medium containing $0.5 \mathrm{M}$-sucrose (Walsby, 1971). The collapse of gas vesicles was determined from the change in turbidity measured by pressure nephelometer (Walsby, 1973). Readings were made on suspensions diluted to give an initial turbidity reading not exceeding 40 nephelometric units (NU). It was shown by the procedure of Deacon \& Walsby (1990) that below $60 \mathrm{NU}$ there was a linear relationship between turbidity and concentration of gasvacuolate filaments of $\boldsymbol{A}$. flos-aquae. The turgor pressure was calculated as $P=\tilde{p}_{\mathrm{c}}-\tilde{p}_{\mathrm{a}}$, where $\tilde{p}_{\mathrm{c}}$ and $\tilde{p}_{\mathrm{a}}$ are the median critical pressures determined in the sucrose solution and culture medium, respectively (Walsby, 1988). The standard deviation of the turgor pressure measurement was calculated as $\left(s_{\mathrm{c}}{ }^{2}+s_{\mathrm{a}}{ }^{2}\right)$, where $s_{\mathrm{c}}$ and $s_{\mathrm{a}}$ are the standard deviations of $\tilde{p}_{\mathrm{c}}$ and $\tilde{p}_{\mathrm{a}}$ respectively.

Gas vesicle volume. The volume of gas vesicle gas space in a sample was determined from the contraction caused by application of pressure in a capillary compression tube (Walsby 1982) using the method of Oliver \& Walsby (1988) with the following modifications. Triplicate measurements were made in quick succession using three compression tubes inserted into three pressure tubes housed in a common thermostatted water jacket. The time required for temperature equilibration was reduced to about $5 \mathrm{~min}$ by filling the pressure tubes with water to improve thermal contact with the compression tubes. The culture samples were enriched with $0.05 \mathrm{M}$-sucrose and degassed by evacuation to prevent subsequent bubble formation in the compression tubes; the addition of sucrose increased the external osmotic pressure, and consequently decreased the turgor pressure by more than one atmosphere, and so prevented gas vesicle collapse on releasing the vacuum. 


\begin{abstract}
Mass and ballast mass of cell constituents. Dry mass was determined by weighing the cyanobacteria collected on filters dried for $48 \mathrm{~h}$ at $80^{\circ} \mathrm{C}$ (Oliver et al., 1985). Protein was determined with the Coomassie blue G-250 reagent (Pierce) using bovine serum albumin as a standard. Carbohydrate was determined with the anthrone reagent (Herbert $e t$ al., 1971) using D-glucose as a standard. The mass of carbohydrate was calculated as $162 / 180$ of the glucose equivalent to allow for the gain in water on hydrolysis. Lipid was determined gravimetrically after extraction into methanol/chloroform/0.15 $\mathrm{M}$-acetic acid $(10: 5: 4$, by vol.) and phase separation into chloroform (Thomas \& Walsby, 1985; modified from Bligh \& Dyer, 1959). All determinations were made in triplicate.
\end{abstract}

\section{Results}

\section{Gas vesicle loss confirmed}

We investigated buoyancy loss and changes in gas vesicle gas volume of Anabaena flos-aquae cultures exposed to high irradiances, in the range $115-142 \mu \mathrm{mol} \mathrm{m} \mathrm{m}^{-2} \mathrm{~s}^{-1}$, in seven different experiments lasting between 18 and $23 \mathrm{~h}$. In each case all of the filaments sank and a substantial decrease in gas vesicle volume was recorded; the average loss represented $51 \%$ of the initial value. In four of the experiments similar cultures were maintained at low irradiance; they all showed small gains in gas vesicle content, representing an $11 \%$ increase over the initial value. The results of these experiments confirmed the findings of Oliver \& Walsby (1984) that in this strain of A. flos-aquae exposure to high irradiance (120-150 $\mu \mathrm{mol}$ $\left.\mathrm{m}^{-2} \mathrm{~s}^{-1}\right)$ for long duration $(24 \mathrm{~h})$ results in a substantial loss of gas vesicles (up to $49 \%$ of the volume initially present).

The irradiance required for loss of buoyancy and gas vesicles

A series of cultures were exposed to light of different photon irradiances for $22 \mathrm{~h}$ to define further the conditions required to cause loss of buoyancy and gas vesicles (Fig. 1). Half of the filaments lost buoyancy after $22 \mathrm{~h}$ at $12 \mu \mathrm{mol} \mathrm{m}^{-2} \mathrm{~s}^{-1}$ and there was total loss at irradiances exceeding $30 \mu \mathrm{mol} \mathrm{m} \mathrm{m}^{-2} \mathrm{~s}^{-1}$; this is in general agreement with the findings of Walsby \& Booker (1980). In contrast there was no significant change in gas vesicle content at irradiances below $17 \mu \mathrm{mol} \mathrm{m}^{-2} \mathrm{~s}^{-1}$; the greatest loss of gas vesicles, over $50 \%$, required exposure to irradiances exceeding $80 \mu \mathrm{mol} \mathrm{m}^{-2} \mathrm{~s}^{-1}$. This experiment was repeated with substantially the same results: $50 \%$ loss of buoyancy after $22 \mathrm{~h}$ at $15 \mu \mathrm{mol} \mathrm{m}^{-2} \mathrm{~s}^{-1}$, and maximum gas vesicle loss at irradiances exceeding $90 \mu \mathrm{mol} \mathrm{m} \mathrm{m}^{-2} \mathrm{~s}^{-1}$, The results of these two experiments suggested that buoyancy loss by Anabaena flos-aquae did not always depend on loss of gas vesicles.

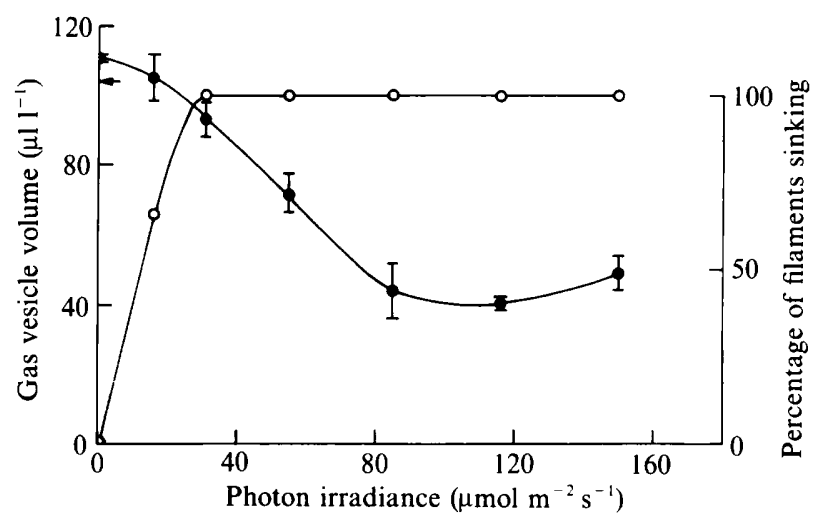

Fig. 1. The buoyancy state of filaments $(O)$ and gas vesicle volume (O) in samples of a culture exposed to different photon irradiances for $22 \mathrm{~h}$. The arrow marks the initial gas vesicle volume.

\section{The proportion of gas vesicle loss caused by turgor rise}

Several experiments were performed to investigate the time course of changes in buoyancy state, gas vesicle volume and turgor pressure. The results of one experiment are shown in Fig. 2. After transfer to high irradiance the turgor pressure increased steadily by $0.24 \mathrm{MPa}(2.4 \mathrm{bar})$ to a maximum of $0.544 \mathrm{MPa}$ after $16 \mathrm{~h}$, and then declined slightly. The gas vesicle volume in the culture increased slightly over the first few hours and then began to decline; by $10 \mathrm{~h}$ it had fallen below its initial value and by $16 \mathrm{~h} 55 \cdot 6 \pm 5 \cdot 5 \%$ of the initial gas vesicle volume had been lost. The following analysis demonstrates that, within the error of measurement, all of this loss could be accounted for by the turgor pressure rise. The gas vesicle critical-pressure distributions at the start of the experiment and after $16 \mathrm{~h}$ at high irradiance are plotted in Fig. 3. The value of $\tilde{p}_{\mathrm{c}}$ (with the filaments in $0.5 \mathrm{M}$-sucrose) rose from $0.540 \pm 0.001$ to $0.641 \pm 0.003$ MPa whereas the value of $\tilde{p}_{\mathrm{a}}$ (with filaments in culture medium) decreased from $0.236 \pm 0.006$ to $0.097 \pm 0.007$ $\mathrm{MPa}$. From this it is calculated that the turgor pressure rose from $0 \cdot 304 \pm 0.006$ to $0.544 \pm 0.008 \mathrm{MPa}$. Measurements made on large-scale graphs of the initial $p_{c}$ distribution (Fig. 3) indicated that a pressure of $0.544 \mathrm{MPa}$ would have caused the collapse of $52.9 \pm 0.6 \%$ of the gas vesicles present at the start of the experiment: this value is within the standard deviation of the percentage that had been collapsed, $55 \cdot 6 \pm 5 \cdot 5 \%$, as determined by compression tube measurements. Much or all of the gas vesicle loss at $16 \mathrm{~h}$ can therefore be explained by the turgor pressure rise.

Also shown in Fig. 3 are derivative curves of the percentage of the original gas vesicles that survived application of different pressures in the culture after $16 \mathrm{~h}$ high irradiation. If the only change from the start of the experiment had been a uniform turgor pressure increase 

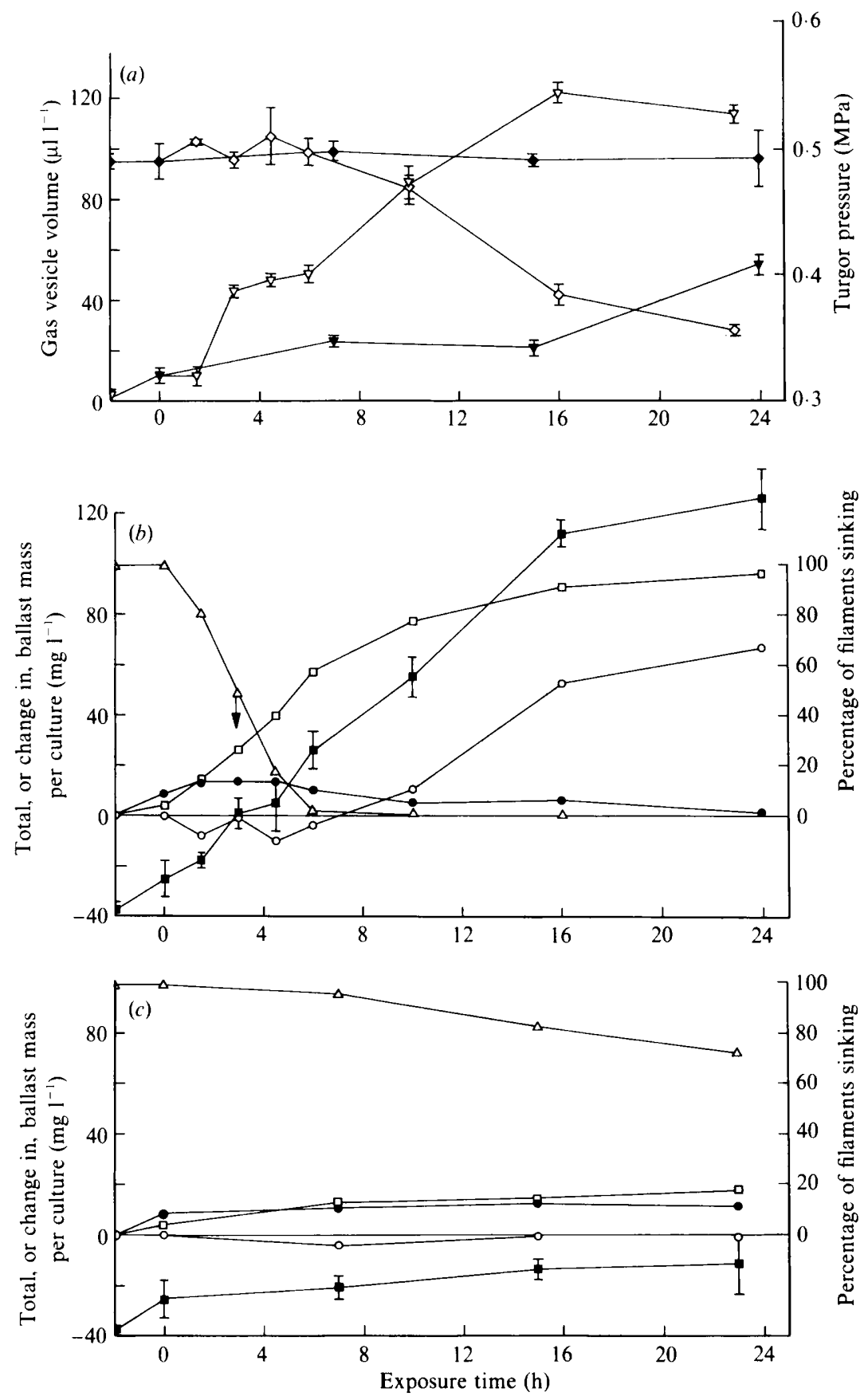

Fig. 2. Changes in cultures transferred to low $\left(5 \mu \mathrm{mol} \mathrm{m} \mathrm{m}^{-2} \mathrm{~s}^{-1}\right)$ or high $\left(135 \mu \mathrm{mol} \mathrm{m} \mathrm{m}^{-2} \mathrm{~s}^{-1}\right)$ photosynthetically active radiation (PAR): (a) turgor pressure $(\nabla, \boldsymbol{\nabla})$ and gas vesicle content $(\diamond, \bullet)$ at low (filled symbols) and high (open symbols) PAR; $(b, c)$ buoyancy state $(\triangle)$ and net ballast masses $(\boldsymbol{D})$ and changes in ballast due to gas vesicles $(O)$, protein $(\bullet)$ and carbohydrate $(\square)$ of filaments in cultures at $(b)$ high and $(c)$ low PAR. The arrow in $(b)$ shows the time $(2.9 \mathrm{~h})$ at which $50 \%$ of the filaments had lost buoyancy and net ballast mass had risen to zero. in all of the cells then the derivative $p_{\mathrm{c}}$ curve (for cells in $0.5 \mathrm{M}$-sucrose) would have been identical with the lower (below 0.45) part of the original $p_{\mathrm{c}}$ curve. The discrepancy is probably explained by variation in the critical pressure distribution and turgor pressure rise in different cells. It is otherwise noted that all of the criteria for gas vesicle collapse by turgor, specified by Dinsdale \& Walsby (1972), are met: (a) the turgor pressure rise was sufficient to explain the collapse of the gas vesicles that were lost; (b) the collapse-pressure curve of gas vesicles in turgid cells starts to fall abruptly from zero applied pressure, indicating that the weakest of the remaining gas vesicles were on the verge of collapsing under turgor pressure alone; and $(c)$ the increase in the $p_{c}$ of gas vesicles, in cells in $0.5 \mathrm{M}$-sucrose, indicates that the weaker gas vesicles had disappeared as a result of the turgor pressure rise. In the final $24 \mathrm{~h}$ sample, however, there was evidence that further gas vesicle collapse occurred which could not be explained by turgor rise (see below). 


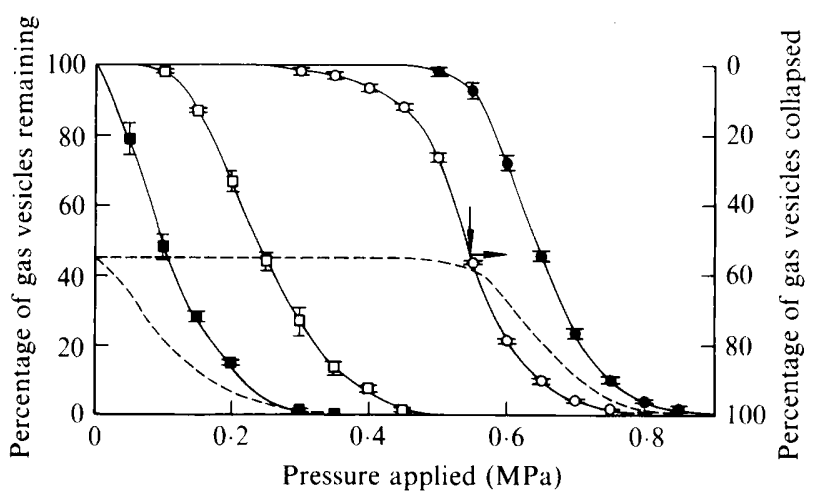

Fig. 3. Distributions of critical pressures $\left(p_{\mathrm{c}}\right)$ of gas vesicles in cells suspended in $0.5 \mathrm{M}$-sucrose $(O, 0)$ and apparent critical pressures $\left(p_{\mathrm{a}}\right)$ of gas vesicles in cells suspended in culture medium $(\square, \boldsymbol{Q})$, at the start of the experiment (open symbols) and after $16 \mathrm{~h}$ exposure to $135 \mu \mathrm{mol}$ $\mathrm{m}^{-2} \mathrm{~s}^{-1}$ (filled symbols). The broken lines are the derivative curves for $p_{\mathrm{c}}$ and $p_{\mathrm{a}}$ of the $45 \%$ of the original gas vesicles remaining. Vertical arrow shows that a turgor pressure of $0.545 \mathrm{MPa}$ (value at $16 \mathrm{~h}$ ) would collapse $46 \%$ (horizontal arrow).

\section{A balance sheet of ballast mass}

The large-scale loss of gas vesicles measured in this experiment would undoubtedly have caused loss of buoyancy in the absence of any other changes in cell constituents. However, while it took $7 \mathrm{~h}$ before the gas vesicle content had decreased below its initial level, $50 \%$ of the filaments had already lost their buoyancy after only $2.9 \mathrm{~h}$ at high irradiance, and by $6 \mathrm{~h}$ less than $2 \%$ of the filaments remained buoyant (Fig. $2 b$ ). This buoyancy loss must have been caused by other changes in the cell constituents, as was demonstrated by analysing the changes in the principal classes of components.

Much of the dry mass of the Anabaena flos-aquae filaments could be accounted for by protein, carbohydrate and lipid. There was an increase in dry mass of $81 \%$ during the $16 \mathrm{~h}$ at high irradiance (Table 1). Protein accounted for $40-50 \%$ of the dry mass in the first $4.5 \mathrm{~h}$ of incubation but it then steadily decreased in both total amount and relative amount until it represented less than $25 \%$ after $24 \mathrm{~h}$. Carbohydrate, in contrast, steadily increased, from $25 \%$ to over $65 \%$ of the total dry mass. Analysis of lipid in some samples indicated that it represented about $11 \%$ of the total mass.

From the mass of each component $\left(M_{\mathrm{c}}\right)$, the ballast mass $\left(M_{\mathrm{b}}\right)$ was calculated, using the equation $M_{\mathrm{b}}=M_{\mathrm{c}}$ $\left(1-\rho_{\mathrm{w}} / \rho_{\mathrm{c}}\right)$, where $\rho_{\mathrm{c}}$ is the density of the component and $\rho_{\mathrm{w}}$ is the density of water, which is $998.2 \mathrm{~kg} \mathrm{~m}^{-3}$ at $20{ }^{\circ} \mathrm{C}$. By taking the value of $\rho_{\mathrm{c}}$ as $1550 \mathrm{~kg} \mathrm{~m}^{-3}$ for carbohydrate, $1300 \mathrm{~kg} \mathrm{~m}^{-3}$ for protein, and $1050 \mathrm{~kg} \mathrm{~m}^{-3}$ for lipid (see Thomas \& Walsby, 1985) the total ballast mass of these components was calculated (Table 1). Since these components accounted for much of the dry matter present, the sum of their ballast masses would account for much of the ballast mass of the cell material. Set against this is the negative ballast provided by the gas vesicle gas space of density $\rho_{\mathrm{c}}=1 \cdot 2 \mathrm{~kg} \mathrm{~m}^{-3}$. With this value added in, the net ballast mass of the gas-vacuolate cells is calculated. (Irrespective of its volume, cell water makes no contribution to the ballast mass, though it does, of course, affect the final density of the cell.)

The net ballast mass of the gas-vacuolate cells showed a steady increase throughout the incubation at high irradiance and became positive after $2.95 \mathrm{~h}$ (Fig. 2b). This is very close to the time of $2.90 \mathrm{~h}$ at which $50 \%$ of the filaments had lost their buoyancy. The analysis of net ballast mass therefore provides a quantitative account of the buoyancy change. When the changes in ballast of the individual components are analysed it is seen that carbohydrate and protein initially made a similar contribution to the rise in ballast over the first $1.5 \mathrm{~h}$, but thereafter protein decreased while carbohydrate continued to increase (Fig. $2 b$ ). In this experiment both the $50 \%$ loss of buoyancy at $3 \mathrm{~h}$ and the $99 \%$ loss of buoyancy at $6 \mathrm{~h}$ were dependent on the increase in carbohydrate ballast.

In the culture kept at $5 \mu \mathrm{mol} \mathrm{m} \mathrm{m}^{-2} \mathrm{~s}^{-1}$ there was a slow increase in ballast and a small decline in buoyancy state, from $99 \%$ down to $70 \%$ filaments floating, over $24 \mathrm{~h}$ (Fig. 2c). Even at this relatively low photon irradiance there was sufficient carbohydrate accumulation to increase the density of the filaments.

\section{Possible loss of gas vesicles unexplained by turgor rise}

At the end of the time-course experiment in high irradiance there was a reduction in gas vesicle content to only $29 \cdot 3 \pm 3.8 \%$ of the volume present at the start (Fig. $2 a$ ). Measurements made on the initial $p_{\mathrm{c}}$ distribution (Fig. 3) indicate that to collapse $70.7 \%$ of the gas vesicles would have required a pressure of $0.580 \mathrm{MPa}$, substantially higher than the maximum value that the turgor pressure reached during exposure to high irradiance $(0.544 \mathrm{MPa}$ at $16 \mathrm{~h})$; in fact the turgor pressure had actually decreased a little at $24 \mathrm{~h}$. A statistical analysis in which $95 \%$ confidence limits are partitioned between estimates of the turgor rise and the loss of gas vesicles shows that the upper estimate of the turgor rise, $0.548 \mathrm{MPa}$, would account for loss of only $55 \%$ of the gas vesicles, whereas the minimum estimate of gas vesicle collapse is $68 \%$, which would require a rise of $0.574 \mathrm{MPa}$. We conclude that either the further loss of gas vesicles between 16 and $24 \mathrm{~h}$ had had some other cause, or the turgor pressure had risen to a higher value and then dropped back again.

The possibility that there might have been fluctuations in turgor pressure after prolonged exposure to high 
Table 1. Balance sheet of changes in cell constituents and their ballast masses

Numbers are means of three measurements (with standard deviations shown in parenthesis).

\begin{tabular}{|c|c|c|c|c|c|c|c|c|c|c|c|}
\hline \multirow[b]{2}{*}{ Treatment } & \multirow[b]{2}{*}{$\begin{array}{c}\text { Time } \\
\text { (h) }\end{array}$} & \multicolumn{4}{|c|}{ Amount per litre of culture } & \multirow[b]{2}{*}{$\begin{array}{c}\begin{array}{c}\text { Ratio* } \\
\text { P+C+L }\end{array} \\
\frac{D}{D}\end{array}$} & \multicolumn{5}{|c|}{ Ballast mass per litre of culture } \\
\hline & & $\begin{array}{l}\text { Gas vesicle } \\
(\mu \mathrm{l})\end{array}$ & $\begin{array}{l}\text { Protein } \\
(\mathrm{mg})\end{array}$ & $\begin{array}{c}\text { Carbohydrate } \\
\text { (mg) }\end{array}$ & $\begin{array}{l}\text { Dry mass } \\
\text { (mg) }\end{array}$ & & $\begin{array}{c}\text { Gas vesi } \\
\text { (mg) }\end{array}$ & sicle & $\begin{array}{l}\text { Protein } \\
\text { (mg) }\end{array}$ & $\begin{array}{c}\text { Carbohydrate } \\
\text { (mg) }\end{array}$ & $\begin{array}{c}\mathrm{G}+\mathrm{P}+ \\
\mathrm{C}+\mathrm{L} \\
(\mathrm{mg})\end{array}$ \\
\hline $\begin{array}{l}\text { Pre- } \\
\text { treatment }\end{array}$ & $\begin{array}{r}-2 \\
0\end{array}$ & $\begin{array}{ll}94 \cdot 7 & (2 \cdot 8) \\
94 \cdot 7 & (7 \cdot 2)\end{array}$ & $\begin{array}{ll}118.2 & (5 \cdot 9) \\
115.0 & (8 \cdot 8)\end{array}$ & $\begin{array}{ll}73 \cdot 4 & (1 \cdot 1) \\
83 \cdot 6 & (2 \cdot 0)\end{array}$ & $\begin{array}{l}290 \cdot 3(17 \cdot 5) \\
352.8\end{array}$ & $\begin{array}{l}0.78 \\
0.77\end{array}$ & $\begin{array}{l}-94.4 \\
-94.5\end{array}$ & $\begin{array}{l}(2 \cdot 8) \\
(7 \cdot 2)\end{array}$ & $\begin{array}{l}27.5(1.4) \\
36.0(2 \cdot 1)\end{array}$ & $\begin{array}{l}27.6(0.4) \\
31.5(0.8)\end{array}$ & $\begin{array}{l}-37 \cdot 7 \\
-25 \cdot 3\end{array}$ \\
\hline $\begin{array}{l}\text { High } \\
\text { irradiance }\end{array}$ & $\begin{array}{l}1 \cdot 5 \\
3 \\
4 \cdot 5 \\
6 \\
10 \\
16 \\
24\end{array}$ & $\begin{array}{rr}102.7 & (0 \cdot 1) \\
95 \cdot 7 & (3 \cdot 1) \\
104.9 & (11 \cdot 3) \\
98.4 & (4 \cdot 9) \\
84.1 & (3.7) \\
42.0 & (4 \cdot 3) \\
27.8 & (2 \cdot 2)\end{array}$ & $\begin{array}{lr}175.9 & (3.6) \\
175.5 & (10.9) \\
175.4 & (9.0) \\
161.8 & (7.8) \\
139.6 & (5.9) \\
145.2 & (5.0) \\
122.0 & (2.5)\end{array}$ & $\begin{array}{l}111.2 \quad(7.0) \\
142.5(11.0) \\
177.8 \quad(9.4) \\
225.1(13.8) \\
278.5(17.9) \\
314.2 \quad(8.5) \\
328.9 \quad(6.1)\end{array}$ & $\begin{array}{rr}369 \cdot 2 & (21.4) \\
351.9 & (2 \cdot 6) \\
364.8 & (7 \cdot 4) \\
394.2 & (14.4) \\
448.7 & (25 \cdot 7) \\
525.3 & (5 \cdot 6) \\
496.1 & \end{array}$ & $\begin{array}{l}0.87 \\
1.00 \\
0.96 \\
1.07 \\
1.01 \\
0.94 \\
0.98\end{array}$ & $\begin{array}{c}-102.4 \\
-95.4 \\
-104.5 \\
-98.1 \\
-83.9 \\
-41.9 \\
-27.7\end{array}$ & $\begin{array}{r}(0 \cdot 1) \\
(3 \cdot 1) \\
(11 \cdot 2) \\
(4 \cdot 9) \\
(3 \cdot 7) \\
(4 \cdot 3) \\
(2 \cdot 2)\end{array}$ & $\begin{array}{l}40.9(0.8) \\
40.8(2.6) \\
40.8(2.1) \\
37.6(1.9) \\
32.4(1.4) \\
33.7(1.2) \\
28.4(0.6)\end{array}$ & $\begin{array}{r}41 \cdot 8(2.6) \\
53.6(4 \cdot 1) \\
66.9(3.5) \\
84.7(5.2) \\
104.8(6.7) \\
118.2(3.2) \\
123.7(2.3)\end{array}$ & $\begin{array}{r}-18 \cdot 0 \\
0 \cdot 7 \\
4 \cdot 8 \\
25 \cdot 9 \\
55 \cdot 1 \\
111 \cdot 7 \\
126 \cdot 1\end{array}$ \\
\hline $\begin{array}{l}\text { Low } \\
\text { irradiance }\end{array}$ & $\begin{array}{r}7 \\
15 \\
23\end{array}$ & $\begin{array}{l}99.0(3.7) \\
95.5 \quad(2.5) \\
95.8(11.1)\end{array}$ & $\begin{array}{ll}164.5 & (3.7) \\
171.2 & (7.6) \\
166.8 & (5.4)\end{array}$ & $\begin{array}{ll}105.6 & (8.0) \\
112.7 & (6 \cdot 7) \\
119.7 & (1.4)\end{array}$ & $\begin{array}{l}275.9(45 \cdot 2) \\
308.9(16.6) \\
350.0\end{array}$ & $\begin{array}{l}1 \cdot 10 \\
1.03 \\
0.91\end{array}$ & $\begin{array}{l}-98 \cdot 7 \\
-95 \cdot 2 \\
-95 \cdot 5(1\end{array}$ & $\begin{array}{r}(3 \cdot 7) \\
(2 \cdot 5) \\
(11 \cdot 1)\end{array}$ & $\begin{array}{l}38.2(0.9) \\
39.8(1.8) \\
38.7(1.3)\end{array}$ & $\begin{array}{l}39.7(3.0) \\
41.9(2.5) \\
45.0(0.5)\end{array}$ & $\begin{array}{l}-20 \cdot 8 \\
-13.6 \\
-11.8\end{array}$ \\
\hline
\end{tabular}

* The ratio of $(\mathrm{P}+\mathrm{C}+\mathrm{L}) / \mathrm{D}$ includes $33.7 \mathrm{mg}$ lipid in each row; the ratio gives the proportion of mass accounted for. C, carbohydrate; $\mathrm{D}$, dry mass; $\mathrm{G}$, gas vesicle; $\mathrm{L}$, lipid; $\mathrm{P}$, protein.

irradiance was investigated by making hourly measurements on another culture that had been incubated for $15 \mathrm{~h}$ at $126 \mu \mathrm{mol} \mathrm{m} \mathrm{m}^{-2} \mathrm{~s}^{-1}$, The turgor pressure rose from an initial value of $0.39 \mathrm{MPa}$ to $0.53 \mathrm{MPa}$ after $16 \mathrm{~h}$ and then remained within $0.013 \mathrm{MPa}$ of this value over the next $6 \mathrm{~h}$ (see Fig. 4). There was, therefore, no evidence of large-scale rises in turgor pressure over this period.

\section{Discussion}

The results obtained here confirm the finding of Oliver \& Walsby (1984) that cells of Anabaena flos-aquae can lose half of their gas vesicles when exposed for many hours to high irradiance, and they demonstrate that this loss can be quantitatively accounted for by the collapse of gas vesicles by rising turgor pressure. The buoyancy loss, however, can be brought about more rapidly (Fig. 2a,b), and perhaps also at lower irradiances (Fig. 1), by carbohydrate accumulation. These findings therefore raise questions about whether gas vesicle collapse by turgor rise has any importance in regulating buoyancy. The answers to these questions lie in an analysis of the changes in cell components.

For a cell to lose buoyancy by accumulating carbohydrate, the increase in carbohydrate ballast must exceed the cell's initial net buoyancy (negative net ballast). Reference to the last column in Table 1 shows that the initial net buoyancy was only $37.7 \mathrm{mg}$ per litre of culture; the carbohydrate ballast increased by this amount within about $4.5 \mathrm{~h}$ at high irradiance. Obviously, the greater the initial net buoyancy the longer it would take for counteraction by carbohydrate accumulation. In the extreme case it might be necessary for gas vesicles to collapse in order for buoyancy to be lost. This was evidently the case in the experiments of Oliver \& Walsby (1984), in which the increase in carbohydrate ballast was insufficient to overcome the initial net buoyancy. In comparing the results of their analyses (Tables 1 and 2 in Oliver \& Walsby, 1984) with those in Table 1 of this paper it is seen that their cultures had a slightly higher initial gas vesicle content (a ratio of gas vesicle ballast to dry mass of 0.35 compared with 0.32 here) and a lower initial carbohydrate content $(0.20$ of dry mass compared with 0.25 here). The major difference, however, was that the relative increase in carbohydrate was less in their cultures (2.5-fold over $24 \mathrm{~h}$, compared with $4 \cdot 5$-fold here). The reason for this is uncertain, but we speculate that it might have been related to the rate of aeration, which supplied $\mathrm{CO}_{2}$ to the cultures. In the complete absence of $\mathrm{CO}_{2}$ there can be no carbohydrate synthesis and it has been demonstrated that there is no turgor rise or buoyancy loss (Walsby 1971; Dinsdale \& Walsby, 1972). When $\mathrm{CO}_{2}$ is not absent but is in limited supply, carbohydrate production might be affected more than turgor rise, as the $\mathrm{K}^{+}$-dependent mechanism of turgor increase would not be directly affected.

A number of other studies have also indicated that $\mathrm{CO}_{2}$ limitation can cause a relative increase in buoyancy in both A. flos-aquae (Booker \& Walsby, 1981; Spencer \& King, 1985) and other gas-vacuolate cyanobacteria (Klemer et al., 1982; Paerl \& Ustach 1982). Spencer \& King (1985) observed that at irradiances of $10 \mu \mathrm{mol} \mathrm{m}^{-2} \mathrm{~s}^{-1}$ buoyancy increased when the $\mathrm{CO}_{2}$ 


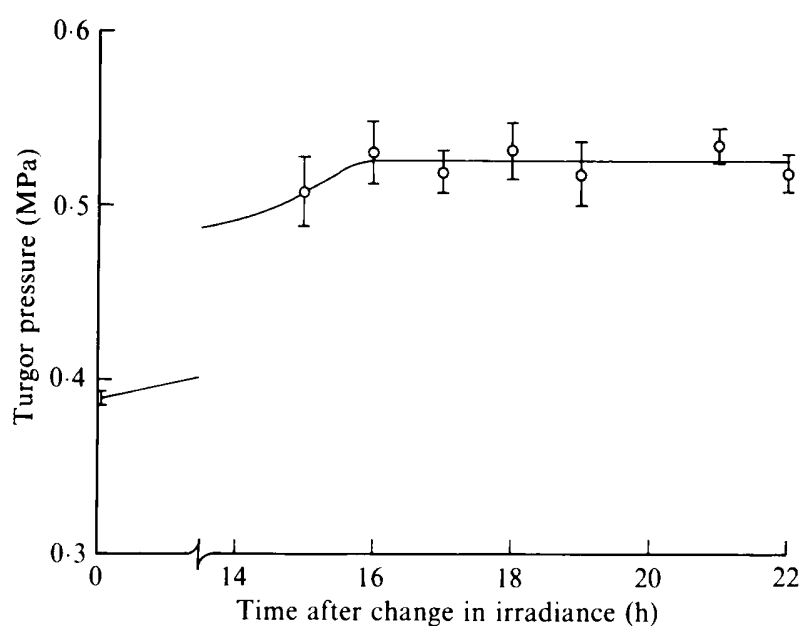

Fig. 4. The turgor pressures at different times after increasing the irradiance from 5 to $126 \mu \mathrm{mol} \mathrm{m}^{-2} \mathrm{~s}^{-1}$. Error bars are standard deviations calculated from three pairs of measurements $\left(p_{\mathrm{c}}-p_{\mathrm{a}}\right)$.

concentration fell below $5 \mu \mathrm{mol} \mathrm{l}^{-1}$ in the culture. Klemer et al. (1982) found that there was an increase in pressure-sensitive turbidity, an indicator of relative gas vesicle content, in cultures of Oscillatoria deprived of $\mathrm{CO}_{2}$. Measurements are now needed of how gas vesicle volume and carbohydrate content change in response to changes in $\mathrm{CO}_{2}$.

The potential advantage of buoyancy-regulating mechanisms that destroy gas vesicles is that they act directly on the sole component that provides buoyancy. The turgor-collapse mechanism is, however, effective only on gas vesicles whose range of critical pressure overlaps with the range of turgor pressure that can be exerted by the cell. The time taken for this mechanism to provide reduction in buoyancy depends on both the turgor rise required and the rate of turgor rise. There has been little investigation of either of these factors. The turgor rise required depends on the difference between the initial turgor and the critical pressure of the weakest gas vesicles, both of which may vary (compare critical pressure distributions illustrated in Walsby 1971, 1980, and Walsby \& Bleything, 1988). The rate of turgor rise is dependent on the irradiance and also on the external $\mathrm{K}^{+}$ concentration (Allison \& Walsby, 1981; Walsby 1980). Previous investigations have shown some relatively rapid rates of turgor increase, which gave gas vesicle collapse in as little as $30 \mathrm{~min}$ (Grant \& Walsby, 1977). This prompted the suggestion that collapse by turgor rise might provide a more rapid response than carbohydrate accumulation (Walsby, 1987); in contrast, the results obtained here, and those obtained with Aphanizomenon by Kromkamp et al. (1986), show that under certain conditions carbohydrate accumulation can provide a more rapid response. Clearly, the effectiveness of the different responses will be greatly affected by the initial physiological state of the cyanobacteria when subjected to increased irradiance. The overall buoyancy state is greatly affected by the availability of nutrients such as nitrogen (Klemer, 1978; Klemer et al., 1982; Spencer \& King, 1985) and phosphate (Konopka et al., 1987a, b; Kromkamp et al., 1989). Quantitative studies of the type described here are now required to elucidate the rates at which the two mechanisms operate under different conditions.

Although the rise in turgor pressure can account for much or all of the substantial gas vesicle loss that occurred in the first $16 \mathrm{~h}$ of incubation at high irradiance, there was an additional loss after $24 \mathrm{~h}$ incubation that could not be definitely attributed to turgor rise. The collapse of the gas vesicles might have been caused by some factor that caused them to become weaker; Buckland \& Walsby (1971) showed that the critical pressures of isolated gas vesicles were decreased by exposure to proteolytic enzymes, detergents, extremes of $\mathrm{pH}$ and high concentrations of certain substances. They commented that if such weakening occurred inside cyanobacterial cells the gas vesicles would collapse under existing turgor pressures and this would provide an additional means of regulating buoyancy. Evidence for such destabilizing factors should now be sought in cells exposed for long times to light of high irradiances.

We thank Dr E. I. Newman for advice on statistical methods. This study was supported by a grant from the Natural Environment Research Council.

\section{References}

Allison, E. M. \& Walsby, A. E . (1981). The role of potassium in the control of turgor pressure in a gas-vacuolate blue-green alga. Journal of Experimental Botany 32, 241-249.

Bligh, E. C. \& Dyer, W. J. (1959). A rapid method of total lipid extraction and purification. Canadian Journal of Biochemistry and Physiology 37, 911-917.

BOOKER, M. J. \& W ALSBY, A. E. (1979). The relative form resistance of straight and helical blue-green algal filaments. British Phycological Journal 14, 141-150.

Booker, M. J. \& WALSBY, A. E. (1981). Bloom formation and stratification by a planktonic blue-green alga in an experimental water column. British Phycological Journal 16, 411-421.

BuCKLAND, B. \& WalsBy, A. E. (1971). A study of the strength and stability of gas vesicles isolated from a blue-green alga. Archiv für Microbiologie 79, 327-337.

Deacon, C. \& Walsby, A. E. (1990). Gas vesicle formation in the dark, and in light of different irradiances, by the cyanobacterium Microcystis sp. British Phycological Journal 25, 133-139.

Dinsdale, M. T. \& WalsBy, A. E. (1972). The interrelations of cell turgor pressure, gas-vacuolation, and buoyancy in a blue-green alga. Journal of Experimental Botany 23, 561-570.

Grant, N. G. \& Walsby, A. E. (1977). The contribution of photosynthate to turgor pressure rise in the planktonic blue-green alga Anabaena flos-aquae. Journal of Experimental Botany 28, 409-415. 
Herbert, D., Phipps, P. J. \& Strange, R. E. (1971). Chemical analysis of microbial cells. Methods in Microbiology 5B, 209-344.

KLEMER, A. R., (1978). Nitrogen limitation of growth and gas vacuolation in Oscillatoria rubescens. Verhandlungen der Internationalen Vereinigung für Theoretische und Angewandte Limnologie 20, 2293-2297.

Klemer, A. R., Feuillade, J. \& Feuillade, M. (1982). Cyanobacterial blooms: carbon and nitrogen limitation have opposite effects on the buoyancy of Oscillatoria. Science 215, 1629-1631).

KONOPKA, A. (1982). Buoyancy regulation and vertical migration by Oscillatoria rubescens in Crooked Lake, Indiana. British Phycological Journal 17, 427-442

Konopka, A.. Brock, T. D. \& Walsby, A. E. (1978). Buoyancy regulation by planktonic blue-green algae in Lake Mendota, Wisconsin. Archiv für Hydrobiologie 83, 524-537.

KonopKa, A., KromKamp, J. C. \& MUR, L. R. (1987a). Buoyancy regulation in phosphate-limited cultures of Microcystis aeruginosa. FEMS Microbiology Ecology 45, 135-142.

KonopKa, A., KromKaMP, J. C. \& MUR, L. R. (1987b). Regulation of gas vesicle content and buoyancy in light- or phosphate-limited cultures of Aphanizomenon flos-aquae (Cyanophyta). Journal of Phycology 23, 70-78.

KromkamP, J. C. \& MUR, L. R. (1984). Buoyant density changes in the cyanobacterium Microcystis aeruginosa due to changes in the cellular carbohydrate content. FEMS Microbiology Letters 25, 105-109.

Kromkamp, J. C., KonopKa, A. \& MUR, L. R. (1986). Buoyancy regulation in a strain of Aphanizomenon flos-aquae (Cyanophyceae): the importance of carbohydrate accumulation and gas vesicle collapse. Journal of General Microbiology 132, 2113-2121.

KromKamp, J. C., KonopKa, A. \& MUR, L. R. (1988). Buoyancy regulation in light-limited continuous cultures of Microcystis aeruginosa. Journal of Plankton Research 10, 171-183.

Kromkamp, J. C, van den Heuvel, A. \& Mur, L. R. (1989), Formation of gas vesicles in phosphorus-limited cultures of Microcystis aeruginosa. Journal of General Microbiology 135 , 1933-1939

VAN LIERE, L. \& WALSBY, A. E. (1982). Interactions of cyanobacteria with light. In The Biology of the Cyanobacteria, pp. 9-45. Edited by N. G. Carr \& B. A. Whitton. Oxford: Blackwell Scientific Publications.

Oliver, R. L. \& WalsBY, A. F. (1984). Direct evidence for the role of light-mediated gas vesicle collapse in the buoyancy regulation of Anahaena flos-aquae (cyanobacteria). Limnology and Oceanography' 29. 879886

OLIVER, R. L. \& WALSBY, A. E. (1988). Buoyancy and suspension of planktonic cyanobacteria. Methods in Enzimology 167, 521-527.

Oliver, R. L., Kinnear, A. J. \& Ganf, G. G. (1981). Measurements of cell density of three freshwater phytoplankters by density gradient centrifugation. Limnology and Oceanography 26, 285-294.

Oliver, R. L., Utkilen, H. C. \& Walsby, A. E. (1982). Mechanisms of buoyancy change in different types of planktonic cyanobacteria. In Proceedings of the 4 th International Symposium on Photosynthetic Prokaryotes, Bombannes, Abstract C35.

Oliver, R. L., Thomas, R. H., Reynolds, C. S. \& Walsby, A. E. (1985). The sedimentation of buoyant Microcystis colonies caused by precipitation with an iron-containing colloid. Proceedings of the Royal Society of London B223, 511-528.

PAeRL, H. W. \& Ustach, J. F. (1982). Blue-green algal scums: an explanation for their occurrence during freshwater blooms. Limno$\log y$ and Oceanography 27, 212-217.
REYNOLDS, C. S. (1973). Growth and buoyancy of Microcystis aeruginosa Kütz. emend. Elenkin in a shallow eutrophic lake. Proceedings of the Roval Society of London B184, 29-50.

REYNOLDS, C. S. (1975). Interrelations of photosynthetic behaviour and buoyancy regulation in a natural population of a blue-green alga. Freshwater Biology 5, 323-338.

van RiJn, J. \& ShIlo, M. (1985). Carbohydrate fluctuations, gas vacuolation and vertical migration of scum-forming cyanobacteria in fishponds. Limnology and Oceanography 30, 1219-1228.

SPENCER, C. N. \& KING, D. L. (1985). Interactions between light, $\mathrm{NH}_{4}^{+}$, and $\mathrm{CO}_{2}$ in buoyancy regulation of Anabaena flos-aquae (Cyanophyceae). Journal of Phycology 21, 194-199.

Thomas, R. H. \& W ALSBY, A. E. (1985). Buoyancy regulation in a strain of Microcystis. Journal of General Microbiology' 131, 799-809.

Thomas, R. H. \& WaLsBY, A. E. (1986). The effect of temperature on recovery of buoyancy by Microcystis. Journal of General Microhiology 137, 1665-1672.

UtKilen, H. C., Oliver, R. L. \& Walsby, A. E. (1985). Buoyancy regulation in a red Oscillatoria unable to collapse gas vacuoles by turgor pressure. Archit für $H_{y}$ drobiologie 102, 319-329.

WALSBY, A. E. (1970). The nuisance algae: curiosities in the biology of planktonic blue-green algae. Water Treatment and Examination 19, 359-373.

WALSBY, A. E. (1971). The pressure relationships of gas vacuoles. Proceedings of the Roval Society of London B178, 301-326.

WALSBY, A. E. (1973). A portable apparatus for measuring relative gas vacuolation, the strength of gas vacuoles, and turgor pressure in planktonic blue-green algae and bacteria. Limnology and Oceanography 18, 653-658.

WALSBY, A. E. (1980). The water relations of gas-vacuolate prokaryotes. Proceedings of the Royal Society of London B208, 73-102.

WALSBY, A. E. (1982). The elastic compressibility of gas vesicles. Proceedings of the Royal Society of London B216, 355-368.

WALSBY, A. E. (1987). Mechanisms of buoyancy regulation by planktonic cyanobacteria with gas vesicles. In The Cyanobacteria, pp. 377-392. Edited by P. Fay \& C. Van Baalen. Amsterdam: Elsevier

W ALSBY, A. E. (1988). Determination of turgor pressure and other cellsolute relations by using gas vesicles as pressure probes. Methods in Enzymology 167, 660-666.

WalsBy, A. E. \& Bleything, A. (1988). The dimensions of cyanobacterial gas vesicles in relation to their efficiency in providing buoyancy and withstanding pressure. Journal of General Microbiology. 134, 2635-2645.

WALSBY, A. E. \& BOOKER, M. J. (1980). Changes in buoyancy of a planktonic blue-green alga in response to light intensity. British Phycological Journal 15, 311-319.

WaLSBY, A. E. \& KLEMER, A. R. (1974). The role of gas vacuoles in the microstratification of a population of Oscillatoria agardhii var. isothrix in Deming Lake, Minnesota. Archic für Hydrobiologie $\mathbf{7 4}$, 375-392.

Walsby, A. E., Utxilen, H. C. \& Johnsen, I. J. (1983). Buoyancy changes of a red coloured Oscillatoria agardhii in Lake Gjersjøen, Norway. Archir für Hydrobiologie 97, 18-38.

Walsby, A. E., Reynolds, C. S., Oliver, R. L. \& Kromkamp, J. (1989). The role of gas vacuoles and carbohydrate content in the buoyancy and vertical distribution of Anabaena minutissima in Lake Rotongaio, New Zealand. Archiv für Hydrchiologie; Ergebnisse der Limnologie 32, 1-25. 